\title{
Growth and productive responses of tropical grass Panicum maximum to nitrate and ammonium supply
}

\author{
Jorge Henrique da Silva Santos¹, Fabiano Daniel De Bona ${ }^{1,2}$, Francisco Antonio Monteiro ${ }^{1}$
}

\footnotetext{
${ }^{1}$ Departamento de Ciência do Solo, Escola Superior de Agricultura "Luiz de Queiroz" (ESALQ), Universidade de São Paulo (USP).

${ }^{2}$ Empresa Brasileira de Pesquisa Agropecuária - Embrapa Trigo.
}

\begin{abstract}
This study was conducted to investigate growth response parameters and forage yield of Panicum maximum Jacq. plants supplied with nitrate $\left(\mathrm{NO}_{3}^{-}\right)$and ammonium $\left(\mathrm{NH}_{4}^{+}\right)$as $\mathrm{N}$ source in a nutrient solution. $\mathrm{Six} \mathrm{NO}_{3}{ }^{-}$and $\mathrm{NH}_{4}^{+}$ combinations were tested at the following proportions: 100-0, 85-15, 70-30, 55-45, 40-60 and 25-75\%. Grass shoot (number of tillers and leaves and leaf surface area) and root (length and surface area) growth parameters and dry matter production exhibited highest values in $P$. maximum plants growing in the nutrient solution supplied with $\mathrm{NO}_{3}^{-}: \mathrm{NH}_{4}^{+}$at the proportions ranging between approximately $70-30$ and $55-45 \%$. The use of $\mathrm{NO}_{3}^{-}: \mathrm{NH}_{4}^{+}$mixture at the ratio of $55-45 \%$ instead of the $\mathrm{NO}_{3}^{-}$ solely as $\mathrm{N}$ source in the nutrient solution enhanced the production of tillers and leaves and the leaf area surface of P. maximum by about 30, 20 and 30\%, respectively. Plants supplied with $\mathrm{NO}_{3}{ }^{-}$and $\mathrm{NH}_{4}^{+}$mixture (55-45\%) showed an increased root length and root surface area by approximately two and six-fold, respectively, compared with $P$. maximum fertilized with $\mathrm{NO}_{3}^{-}$exclusively in the growth medium. Supplying $\mathrm{N}$ in the nutrient solution as $\mathrm{NO}_{3}^{-}$or $\mathrm{NH}_{4}^{+}$exceeding approximately 70 or $50 \%$, respectively, caused a diminished $P$. maximum forage yield. Enhanced $\mathrm{N}$-use efficiency associated with $P$. maximum plants supplied with a $\mathrm{NO}_{3}^{-}$and $\mathrm{NH}_{4}^{+}$mixture in the growth medium supports the assumption that it is possible to increase plant production by managing $\mathrm{N}$ fertilization based on quality ( $\mathrm{N}$ forms) of $\mathrm{N}$ fertilizers applied in pasture systems.
\end{abstract}

Key Words: forage production, nitrogen nutrition, nitrogen-use efficiency, plant development, tillering

\section{Introduction}

Forage grasses are widespread on the entire world and constitute one of the most important food sources for grazing animals. The intensity of forage production depends basically on the plant tillering and leaf development and growth processes (De Bona \& Monteiro, 2010a). Such plant processes are genetically controlled and can be altered by the management of plant growth conditions (phenotype control). Among the changeable plant growth conditions, growth medium such as water and nutrient availability play a major role in determining forage dry matter yield.

Considering soil fertility and plant nutrition status, previous results have demonstrated the importance of nitrogen $(\mathrm{N})$ supply on the improvement of forage grass production (Vicente-Chandler, 1973; Laurialt et al., 2002; Reich et al., 2003; De Bona \& Monteiro, 2010b). In fact, many tropical forage grasses are $\mathrm{C}_{4}$ plants, which are highly responsive to $\mathrm{N}$ fertilization. A classical study of VicenteChandler (1973), conducted in Puerto Rico soils under no water or nutrient limitations, reported that dry matter yields of tropical forage grasses such as napiergrass (Pennisetum purpureum Schumach.), guineagrass (Panicum maximum Jacq.), ruzigrass [Urochloa ruziziensis (R. Germ. \& C.M.
Evrard) Morrone \& Zuloaga] and stargrass (Cynodon nlemfuensis Vanderyst) increased with $\mathrm{N}$ rates up to $896 \mathrm{~kg} / \mathrm{ha}$. In spite of positive growth responses, very high $\mathrm{N}$ additions to grasslands could reduce the $\mathrm{N}$-use efficiency as well as enhance the environment potential contamination by nitrate leaching (Babiker et al., 2004). Thus, to manage $\mathrm{N}$ fertilization aiming to enhance plant production without increasing the $\mathrm{N}$ rate applied is a big challenge for the scientific research and farmers practice.

Among the commercial $\mathrm{N}$ fertilizers, different $\mathrm{N}$ forms [nitrate $\left(\mathrm{NO}_{3}^{-}\right)$and ammonium $\left(\mathrm{NH}_{4}^{+}\right)$] or mixtures of $\mathrm{N}$ forms can be chosen: urea, ammonium nitrate, ammonium sulfate, mono-ammonium phosphate, di-ammonium phosphate, calcium nitrate or potassium nitrate (Havlin et al., 2005). These nitrogen sources vary not only in total $\mathrm{N}$ content, but also in the predominant ionic form $\left(\mathrm{NO}_{3}{ }^{-}\right.$or $\left.\mathrm{NH}_{4}^{+}\right)$in which $\mathrm{N}$ is supplied to the plants. It is known that the plant physiological responses depend on the $\mathrm{N}$ form absorbed by the roots (Marschner, 1995). These responses certainly influence plant growth performance and dry matter yield (McCrimmon et al., 1992). Wang \& Below (1992) tested two wheat (Triticum aestivum L.) cultivars and had higher number of tillers when they supplied $\mathrm{NO}_{3}{ }^{-}$and $\mathrm{NH}_{4}^{+}$at 75-25 or 50-50\%, respectively, than solely $\mathrm{NO}_{3}^{-}$or $\mathrm{NH}_{4}^{+}$. 
Some studies on plant hormones have been carried out and found that plant morphogenesis (root and shoot) may change according to the $\mathrm{NO}_{3}{ }^{-}$and $\mathrm{NH}_{4}{ }^{+}$supply (Walch-Liu et al., 2000; Rahayu et al., 2005; Walch-Liu et al., 2006). Supported by these interesting results obtained mainly with crop plants, the growth of tropical grasses is expected to be also affected by $\mathrm{N}$ forms supplied in the growth medium. Thus, the objective of this study was to evaluate the general growth response parameters and forage production of the tropical grass Panicum maximum Jacq. supplied with $\mathrm{NO}_{3}^{-}$ and $\mathrm{NH}_{4}^{+}$as $\mathrm{N}$ in nutrient solution.

\section{Material and Methods}

The experiment was carried out during the summer season under greenhouse conditions $\left(22-35{ }^{\circ} \mathrm{C}\right.$; light: dark $=16: 8$ hours). Panicum maximum Jacq. cv. Aruana (Aruana guineagrass) seeds were germinated on a sterile sand medium. After about $14 \mathrm{~d}$, five grass seedlings were transplanted into plastic pots $(20 \mathrm{~cm}$ height; $15.5 \mathrm{~cm}$ diameter; and 3.6 L volume) containing an inert substrate (ground quartz with diameter between 2 and $8 \mathrm{~mm}$ ). Plants were irrigated with a complete nutrient solution based on Hoagland \& Arnon (1950), with six $\mathrm{NO}_{3}^{-}: \mathrm{NH}_{4}^{+}$ratios (Table 1). Nitrogen, phosphorus $(\mathrm{P})$, potassium $(\mathrm{K})$, calcium $(\mathrm{Ca})$, magnesium $(\mathrm{Mg}$ ) and sulphur $(\mathrm{S})$ were homogeneously supplied in the nutrient solution at the concentrations of 15 , $1,6,5,2$ and $2 \mathrm{mmol} / \mathrm{L}$, respectively. The nutrient solution was replaced every $10 \mathrm{~d}$ and the content of $\mathrm{N}$ forms in the growth medium was continuously checked by using $\mathrm{NO}_{3}^{-}$and $\mathrm{NH}_{4}^{+}$tests. The treatments of proportions of $\mathrm{N}$ in different forms were arranged in a randomized complete block design, with four replications.

Plant shoots were harvested twice: $28 \mathrm{~d}$ after transplanting and $22 \mathrm{~d}$ after the first harvest. Roots were collected at the second shoot harvest time. The harvested material was dried in a forced air-ventilated oven at $65{ }^{\circ} \mathrm{C}$ until constant mass. At the harvesting time, the number of tillers and leaves and leaf area of plants were also determined. Leaf surface area was determined by using a leaf area machine model LI 3100 (LI-COR, NE, USA). So as to determine the root surface area and length, part of the grass root system (approximately 20\%) was stained with a gentian violet solution $(1000 \mathrm{~mL}$ distilled water + $50 \mathrm{mg}$ of violet gentian) for 24 hours, put on an acetate sheet to avoid root overlapping, and scanned with a HP Scanjet 3670 (300 dpi, Hewlett-Packard Development Company, Texas, USA). Subsequently, total root area and length of scanned grass root images were calculated using the software SIARCS (Integrated Analysis System of Roots and Soil Cover, version 3.0) (Crestana et al., 1994).

The concentrations of total $\mathrm{N}, \mathrm{N}_{-} \mathrm{NO}_{3}^{-}$and $\mathrm{N}_{-} \mathrm{NH}_{4}^{+}$ were determined in ground ( $1 \mathrm{~mm}$ particle) dry root and shoot material. Total $\mathrm{N}$ in the plant tissue was determined according to Nelson \& Sommers (1973). Nitrogen content was used to estimate the amounts of $\mathrm{N}$ extracted by the grass from the nutrient solution. Nitrate and $\mathrm{NH}_{4}^{+}$concentrations in the plant material were determined using the micro Kjeldahl method (Tedesco et al., 1995).

Disregarding the plant root parameters, all other results (shoot parameters) presented in this study represent the mean of both harvests because the plant responses to the treatments with $\mathrm{N}$ forms were similar in both growth cycles. Statistical analysis was performed using the statistical software SAS (Statistical Analysis System, version 9.1.2). Data were evaluated by ANOVA for the $\mathrm{NO}_{3}^{-}: \mathrm{NH}_{4}^{+}$ratios in the nutrient solution. Means were compared by Tukey's test at the 5\% significance level. Regression studies for the $\mathrm{NO}_{3}^{-}: \mathrm{NH}_{4}^{+}$ratios or $\mathrm{NH}_{4}^{+}$replacement for $\mathrm{NO}_{3}^{-}(\%)$ in the nutrient solution were performed through GLM procedures.

Table 1 - Chemical composition of the nutrient solution according to the $\mathrm{NO}_{3}^{-}: \mathrm{NH}_{4}^{+}$ratio supply

\begin{tabular}{|c|c|c|c|c|c|c|}
\hline \multirow{2}{*}{ Salts } & \multicolumn{6}{|c|}{$\mathrm{NO}_{3}^{-}: \mathrm{NH}_{4}^{+}$ratio (\%) } \\
\hline & $100-0$ & $85-15$ & $70-30$ & $55-45$ & $40-60$ & $25-75$ \\
\hline $\mathrm{KH}_{2} \mathrm{PO}_{4}(\mathrm{mmol} / \mathrm{L})$ & 1 & 1 & 1 & 0 & 0 & 0 \\
\hline $\mathrm{KCl}(\mathrm{mmol} / \mathrm{L})$ & 0 & 0.5 & 3 & 5 & 6 & 6 \\
\hline $\mathrm{Ca}\left(\mathrm{NO}_{3}\right),(\mathrm{mmol} / \mathrm{L})$ & 5 & 3 & 2 & 0.75 & 0 & 0 \\
\hline $\mathrm{CaCl}_{2}(\mathrm{mmol} / \mathrm{L})$ & 0 & 2 & 3 & 4.25 & 5 & 5 \\
\hline $\mathrm{MgSO}_{4}(\mathrm{mmol} / \mathrm{L})$ & 2 & 2 & 2 & 2 & 1 & 0 \\
\hline $\mathrm{NH}_{4}^{4} \mathrm{Cl}(\mathrm{mmol} / \mathrm{L})$ & 0 & 0 & 0 & 0 & 0 & 2.5 \\
\hline $\mathrm{NH}_{4}^{4} \mathrm{H}_{2} \mathrm{PO}_{4}(\mathrm{mmol} / \mathrm{L})$ & 0 & 0 & 0 & 1 & 1 & 1 \\
\hline$\left(\mathrm{NH}_{4}\right)_{2}^{2} \mathrm{SO}_{4}(\mathrm{mmol} / \mathrm{L})$ & 0 & 0 & 0 & 0 & 1 & 2 \\
\hline
\end{tabular}

All treatments received a similar content of micronutrients in the nutrient solution as follows: $46 \mu \mathrm{mol} / \mathrm{L}_{\text {of }} \mathrm{BBO}_{3}, 9 \mu \mathrm{mol} / \mathrm{L} \mathrm{of} \mathrm{MnCl}_{2} .4 \mathrm{H}_{2} \mathrm{O}, 0.7 \mu \mathrm{mol} / \mathrm{L}$ of ZnCl, $0.2 \mu \mathrm{mol} / \mathrm{L}$ of $\mathrm{CuCl}_{2} \cdot 2 \mathrm{H}_{2} \mathrm{O}, 0.08 \mu \mathrm{mol} / \mathrm{L}$ of $\mathrm{Na}_{2} \mathrm{MoO}_{4} \cdot 2 \mathrm{H}_{2} \mathrm{O}$ and $100 \mu \mathrm{mol} / \mathrm{L}$ of $\mathrm{Fe}(\mathrm{III})$-EDTA. 


\section{Results}

The supply of $\mathrm{N}$ in the nutrient solution through different $\mathrm{NO}_{3}^{-}: \mathrm{NH}_{4}^{+}$ratios significantly affected the $P$. maximum growth responses by promoting changes in the total tiller and leaf emission and leaf area expansion (Figures 1A, 1B and $1 \mathrm{C}$, respectively). The use of the $\mathrm{NO}_{3}^{-}: \mathrm{NH}_{4}^{+}$mixture at the ratio of $55-45 \%$ instead of the $\mathrm{NO}_{3}^{-}$solely as $\mathrm{N}$ source in the nutrient solution enhanced the emission of tillers and leaves and the total leaf area of $P$. maximum by about 30,20 and $30 \%$, respectively.

As expected, the shoot dry matter production (Figure 1D) of the forage grass reflected the plant growth responses (Figures $1 \mathrm{~A}, 1 \mathrm{~B}$ and $1 \mathrm{C}$ ) to the $\mathrm{NO}_{3}^{-}: \mathrm{NH}_{4}^{+}$ratios in the nutrient solution. Thus, the highest forage production was found in the P. maximum plants grown in the nutrient solution containing $\mathrm{NO}_{3}^{-}: \mathrm{NH}_{4}^{+}$at the proportions of 70-30 and $55-45 \%$. Using $\mathrm{N}$ in the nutrient solution as $\mathrm{NO}_{3}{ }^{-}$or $\mathrm{NH}_{4}^{+}$ exceeding about 70 or $50 \%$, respectively, resulted in low P. maximum forage yield.

Undoubtedly, the development and growth of plant shoot depends on adequate root growth. In the present study, root length and root surface area data (Figures 2A and 2B) showed a similar response to the shoot parameters (Figures $1 \mathrm{~A}, 1 \mathrm{~B}$ and $1 \mathrm{C}$ ) in relation to the $\mathrm{NO}_{3}^{-}: \mathrm{NH}_{4}^{+}$ratio supply in the nutrient solution. Therefore, forage plants growing under a nutrient solution with $\mathrm{N}$ provided as a mixture of $\mathrm{NO}_{3}{ }^{-}$and $\mathrm{NH}_{4}^{+}$at the ratio of 55-45\% exhibited highest root length and root surface area. Despite the response similarities, the root system (Figures $2 \mathrm{~A}$ and $2 \mathrm{~B}$ ) of the grass plants was more intensively affected by the $\mathrm{NO}_{3}^{-}: \mathrm{NH}_{4}^{+}$ratios than the shoot parameters (Figures 1A, 1B and 1C). Thus, the use of the $\mathrm{NO}_{3}^{-}: \mathrm{NH}_{4}^{+}$mixture at the ratio of $55-45 \%$ instead of the $\mathrm{NO}_{3}{ }^{-}$form alone in the growth medium increased the forage grass root length and root surface area by approximately two and six-fold, respectively.

Similarly to root growth parameters, the root dry matter of $P$. maximum reached the highest values when the plants grew in the nutrient solution supplied with a $\mathrm{NO}_{3}^{-}: \mathrm{NH}_{4}^{+}$ ratio of $55-45 \%$ (Figure 2C). The predominance of $\mathrm{NO}_{3}^{-}$ (approximately $85 \%$ or more) or $\mathrm{NH}_{4}^{+}$(approximately $60 \%$ or more) as $\mathrm{N}$ in the growth medium was accompanied by severe grass root dry matter decreases.

Studying the variations in grass growth and productive parameters due to $\mathrm{NH}_{4}^{+}$replacement with $\mathrm{NO}_{3}^{-}$as $\mathrm{N}$ source in the nutrient solution (Table 2), maximal plant variable responses were associated with $\mathrm{NO}_{3}^{-}: \mathrm{NH}_{4}^{+}$ratios ranging from 60-40 to 72-28 (average value of 68-32).

Nitrogen concentration in shoot tissue of the forage plant was affected significantly by the $\mathrm{NO}_{3}^{-}: \mathrm{NH}_{4}^{+}$ratios provided in the nutrient solution and ranged between 13.5 and $24.0 \mathrm{~g} / \mathrm{kg}$ (Figure 3A). Due to the nutrient dilution phenomenon, $\mathrm{N}$ concentration in P. maximum grass shoot varied inversely to the dry matter yield changes (Figure 1D). Forage plants grown with a nutrient solution high in $\mathrm{NH}_{4}^{+}$ showed decreased $\mathrm{N}$ absorption and accumulation. Unlike total $\mathrm{N}$ content, the concentration of free $\mathrm{N}^{-\mathrm{NO}_{3}}{ }^{-}$and $\mathrm{N}-\mathrm{NH}_{4}{ }^{+}$ in the shoot tissue of $P$. maximum did not change in response to $\mathrm{NO}_{3}^{-}: \mathrm{NH}_{4}^{+}$ratios in the nutrient solution, averaging approximately 0.50 and $0.45 \mathrm{~g} / \mathrm{kg}$, respectively.
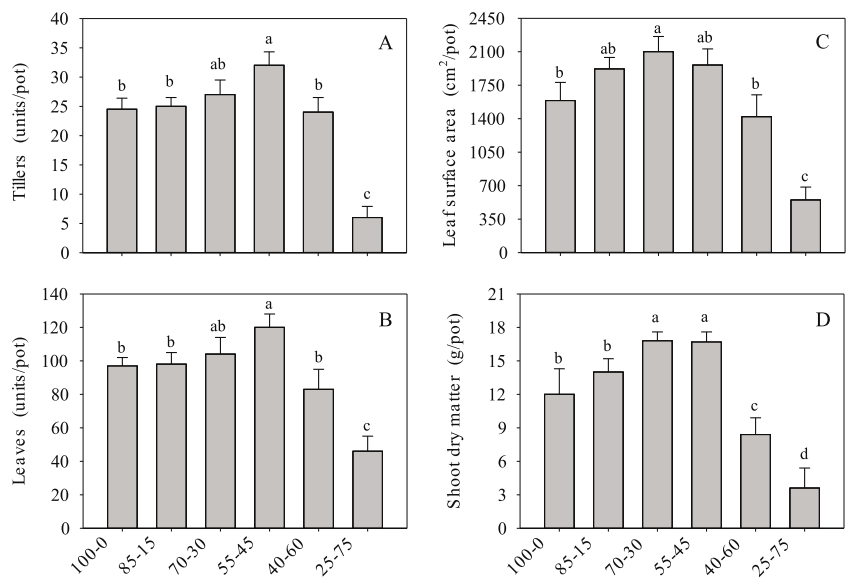

$\mathrm{NO}_{3}{ }^{-}: \mathrm{NH}_{4}{ }^{+}$in the nutrient solution (\%)

Bars with different letters differ by Tukey's test at $5 \%$ of significance $(n=4)$.

Figure 1 - Shoot growth parameters [total number of tillers (A) and leaves (B), and leaf surface area (C)] and shoot dry matter production (D) of the forage grass Panicum maximum supplied with nitrate $\left(\mathrm{NO}_{3}{ }^{-}\right)$and ammonium $\left(\mathrm{NH}_{4}^{+}\right)$as $\mathrm{N}$ source in the nutrient solution.

Table 2 - Regression analysis for estimation of Panicum maximum growth and productive responses as related to ammonium $(0,15,30,45$, 60 and $75 \%$ ) replacement with nitrate as $\mathrm{N}$ source in the nutrient solution

\begin{tabular}{|c|c|c|c|}
\hline Plant variable & Adjusted regression & Coefficient of determination $\left(\mathrm{R}^{2}\right)$ & Estimated $\mathrm{NO}_{3}^{-}: \mathrm{NH}_{4}^{+}$ratio for maximum variable response \\
\hline Number of tillers & $Y=21.66+0.62 x-0.010 x^{2}$ & 0.83 & $69-31$ \\
\hline Number of leaves & $Y=90.07+1.61 x-0.028 x^{2}$ & 0.85 & $71-29$ \\
\hline Leaf surface area & $Y=1550+39.83 x-0.70 x^{2}$ & 0.99 & $72-28$ \\
\hline Shoot dry matter & $Y=11.46+0.35 x-0.0062 x^{2}$ & 0.93 & $72-28$ \\
\hline Root length & $Y=8.76+0.57 x-0.0076 x^{2}$ & 0.79 & $64-36$ \\
\hline Root surface area & $Y=68.93+49.76 x-0.66 x^{2}$ & 0.55 & $60-40$ \\
\hline Root dry matter & $Y=7.16+0.36 x-0.056 x^{2}$ & 0.88 & $68-32$ \\
\hline
\end{tabular}



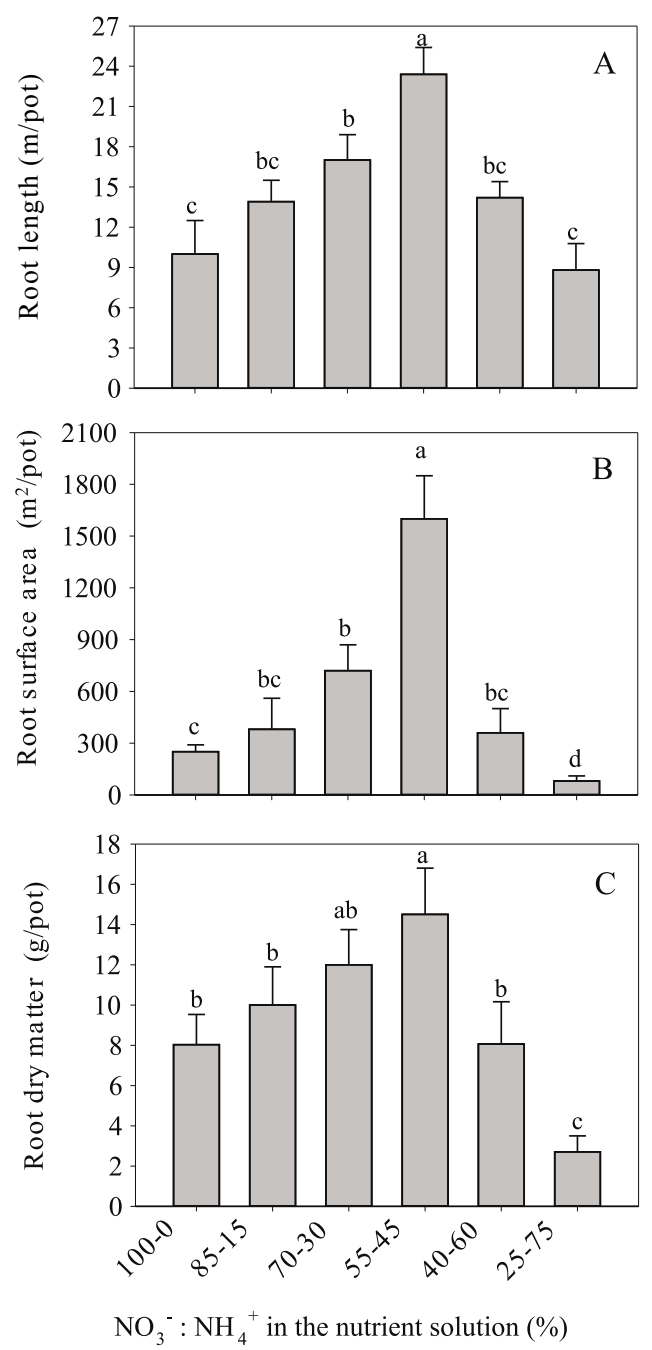

Bars with different letters differ by Tukey's test at $5 \%$ of significance $(n=4)$.

Figure 2 - Root growth parameters [total root length (A) and root surface area (B)] and root dry matter production (C) of the forage grass Panicum maximum supplied with nitrate $\left(\mathrm{NO}_{3}^{-}\right)$and ammonium $\left(\mathrm{NH}_{4}^{+}\right)$as $\mathrm{N}$ source in the nutrient solution.

The supply of $\mathrm{NO}_{3}^{-}$and $\mathrm{NH}_{4}^{+}$in the growth medium resulted in significant changes in the $\mathrm{N}$ concentration of the $P$. maximum roots, which exhibited similar values to the shoot tissue (Figure 3A), ranging from 11.5 to $20.5 \mathrm{~g} / \mathrm{kg}$ (Figure 3B). Forage grass growing under a nutrient solution with $\mathrm{N}$ provided exclusively or mostly as $\mathrm{NO}_{3}^{-}(100-0$ and 85-15 as $\mathrm{NO}_{3}^{-}: \mathrm{NH}_{4}^{+}$ratio) showed the highest concentration of total $\mathrm{N}$ and free $\mathrm{N}-\mathrm{NO}_{3}{ }^{-}$and $\mathrm{N}-\mathrm{NH}_{4}{ }^{+}$in the root tissue. Similarly to the shoot tissue (Figure 3A), plants growing under a nutrient solution where the $\mathrm{NO}_{3}^{-}: \mathrm{NH}_{4}^{+}$ratio was lower than approximately 1.0 showed a strong decrease in the $\mathrm{N}$ extracted by these plants (Figure 3B).

Based on the plant dry matter production (Figures 1D and $2 \mathrm{C}$ ) and the $\mathrm{N}$ content in plant tissue data (Figures $3 \mathrm{~A}$ and $3 \mathrm{~B}$ ), the N-use efficiency (NUE) showed greatest values when $\mathrm{N}$ was provided in the nutrient solution for P. maximum through the mixture of $\mathrm{NO}_{3}^{-}$and $\mathrm{NH}_{4}^{+}$at proportions ranging between $70-30$ and $55-45 \%$ (Figure $3 \mathrm{C}$ ).

\section{Discussion}

Since homogeneous $\mathrm{N}$ application was performed in the nutrient solution and no growth-limiting $\mathrm{N}$ concentration (Lavres Júnior \& Monteiro, 2006) was noticed in the $P$. maximum tissues (Figures $3 \mathrm{~A}$ and $3 \mathrm{~B}$ ), the grass growth responses to $\mathrm{NO}_{3}{ }^{-}$and $\mathrm{NH}_{4}{ }^{+}$treatments cannot be attributed to limited $\mathrm{N}$ availability or uptake. This clearly indicates that the remarkable changes in the forage production of P. maximum (varying from 3.6 to $16.8 \mathrm{~g} / \mathrm{pot}$ ) were associated with modified shoot and root development and growth parameters (Figures 1 and 2) due to the $\mathrm{N}$ forms supplied as $\mathrm{N}$ source. Involved in the increase of grass demography in field conditions and, consequently forage production potential, the number of tillers/plant was enhanced by the use of the $\mathrm{N}$ mixture $\left(\mathrm{NO}_{3}: \mathrm{NH}_{4}^{+}\right.$ratio of $55-45 \%$ ), also increasing the leaf production capacity of $P$. maximum grass. This finding is very important since the number of live leaves/tiller of forage grasses remains constant throughout the life of the plant. Actually, leaves are produced continuously, but each time a new leaf appears, the oldest leaf on the tiller initiates the senescence process and dies (Hunt, 1965). Another relevant shoot modification observed in grass plants fertilized with $\mathrm{NO}_{3}{ }_{3}^{-}$and $\mathrm{NH}_{4}^{+}$ mixture was the increased leaf surface area. Besides directly increasing the forage yield potential, larger leaves are able to intercept more light (solar radiation), amending within certain limits the light-use efficiency and plant canopy photosynthesis (Hirose \& Bazzaz, 1998).

Previous studies also reported that many plant species perform better under the supply of $\mathrm{N}$ as a mixture of $\mathrm{NO}_{3}{ }_{3}^{-}$and $\mathrm{NH}_{4}^{+}$and, comparable to the results presented in this paper, shoot yield was accompanied by increased tillering (Wang \& Below, 1992; Wang \& Below, 1996) and leaf surface area (Cox \& Reisenauer, 1973; Walch-Liu et al., 2000; Helali et al., 2010) of $\mathrm{NO}_{3}{ }^{-}$and $\mathrm{NH}_{4}^{+}$mixturefertilized plants. Tillering of wheat plants was highly influenced by fertilization with mixed $\mathrm{N}$ sources (Wang \& Below, 1996). Regarding leaf morphogenesis, Walch-Liu et al. (2000), investigating the effect of $\mathrm{N}$ forms on the growth of tobacco (Nicotiana tabacum L.) cultivated in a nutrient solution, found higher leaf expansion rate and leaf surface area associated with plants fertilized with a mixture of $\mathrm{NO}_{3}{ }_{3}^{-}$and $\mathrm{NH}_{4}{ }^{+}$than exclusive $\mathrm{NH}_{4}{ }^{+}$-fertilized plants. These authors have demonstrated by microscopic analysis of the epidermis of fully expanded leaves that cell number and cell 
size decrease by 50 and $30 \%$, respectively, with application of $\mathrm{NH}_{4}^{+}$, which indicates that both cell division and cell elongation were affected. At least in part, the described results can be attributed to the action of the plant hormone cytokinin (Takei et al., 2002). Cytokinin is recognized as crucial signaling molecules that control plant growth and development by promoting cell division, cell expansion and
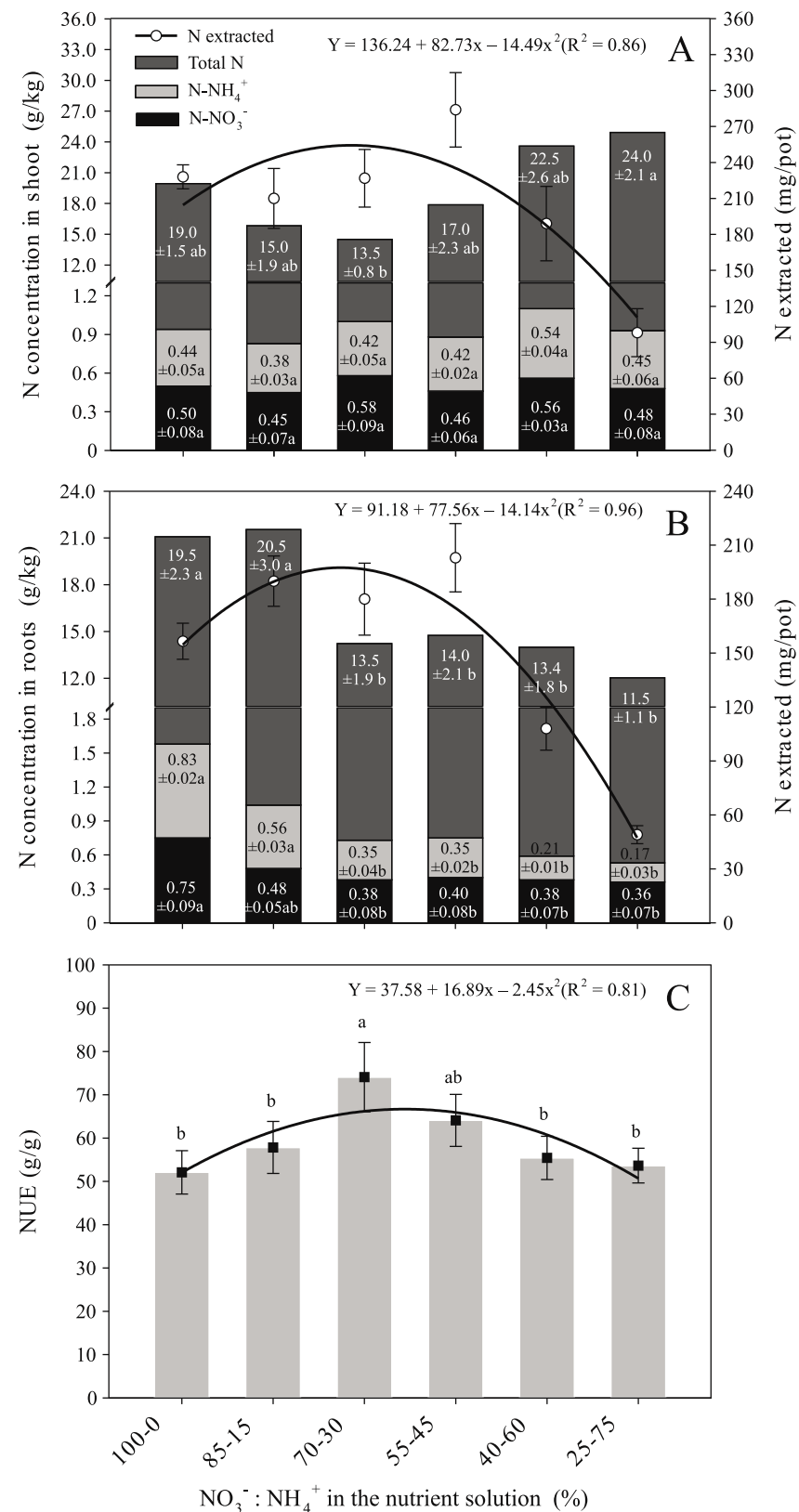

Bars with different letters differ by Tukey's test at $5 \%$ of significance $(n=4)$.

Figure 3 - Shoot and root nitrogen $(\mathrm{N})$ nutritional status parameters [total $\mathrm{N}, \mathrm{N}$-nitrate $\left(\mathrm{N}-\mathrm{NO}_{3}^{-}\right)$and $\mathrm{N}$-ammonium $\left(\mathrm{N}-\mathrm{NH}_{4}^{+}\right)$ concentration] (A, B), N extracted by plant tissues $(\mathrm{A}, \mathrm{B})$ and $\mathrm{N}$-use efficiency (NUE) (C) of the forage grass Panicum maximum supplied with $\mathrm{NO}_{3}^{-}$and $\mathrm{NH}_{4}^{+}$ as $\mathrm{N}$ source in the nutrient solution. axillar bud outgrowth (shoot branching) (Ongaro \& Leyser, 2008). Moreover, research findings have demonstrated that cytokinin synthesis and root-to-shoot translocation can be increased by applying the mixture of $\mathrm{NO}_{3}{ }^{-}$and $\mathrm{NH}_{4}{ }^{+}$as $\mathrm{N}$ source in the growth medium (Smiciklas \& Below, 1992; Wang \& Below, 1996; Walch-Liu et al., 2000).

In the present study, shoot production and growth responses certainly also reflect the $\mathrm{NO}_{3}^{-}: \mathrm{NH}_{4}^{+}$ratio effects on $P$. maximum root system, which was markedly more influenced by $\mathrm{N}$ forms in the nutrient solution than the aboveground grass tissues (Figures 1 and 2). The plant root system plays a major role in plants growing in soil because it is responsible particularly by the nutrients and water uptake. Plant $\mathrm{N}$ nutrition status or $\mathrm{N}$ availability in medium influencing the growth and development of roots has been reported by other researchers (Drew, 1975; Gerendás et al., 1997; Zhang et al., 1999; Lima et al., 2010). These findings suggested that both $\mathrm{NO}_{3}^{-}$(Gerendás et al., 1997; Zhang et al., 1999) and $\mathrm{NH}_{4}^{+}$(Drew, 1975; Lima et al., 2010) are able to stimulate root branching and lateral root elongation through the expression of plant growth regulator genes (auxin and/or cytokinin) responsive to the presence of the $\mathrm{N}$ form in the environment. However, it is important to highlight that a very high content of available $\mathrm{NO}_{3}$ to the plants represses the lateral root development by a systemic inhibition possibly regulated by the accumulation of $\mathrm{NO}_{3}^{-}$(Figure 3B) in the plant tissue (Zhang et al., 1999; Zhang \& Forde, 2000; Walch-Liu et al., 2006). Also, a high content of $\mathrm{NH}_{4}^{+}$in the growth medium potentially impairs the root growth and development due to the $\mathrm{NH}_{4}^{+}$toxicity phenomenon (Gerendás et al., 1997; Britto \& Kronzucker, 2002). Agreeing with the exposed theories, roots of $P$. maximum exhibited greatest absolute length, surface area and dry matter (Figure 2) when $\mathrm{N}$ was supplied in the nutrient solution at the intermediate $\mathrm{NO}_{3}^{-}: \mathrm{NH}_{4}^{+}$ratio of $55-45 \%$.

Taking into consideration the $P$. maximum shoot and root yield and growth parameters (Figures 1 and 2), it is easy to visualize that in general $\mathrm{NO}_{3}^{-}: \mathrm{NH}_{4}^{+}$ratios in the nutrient solution with the predominance of $\mathrm{NO}_{3}$ (approximately $85 \%$ or more) or exceeding about $50 \%$ of the $\mathrm{N}$ as $\mathrm{NH}_{4}^{+}$resulted in low values of the response variables. Indeed, grass growth parameters were more severely impaired by high content of $\mathrm{NH}_{4}^{+}$(about 75\%) in the growth medium than $\mathrm{NO}_{3}^{-}$as exclusive $\mathrm{N}$ source. This remarkable decrease in plant growth and development when $\mathrm{NH}_{4}^{+}$was superior to $\mathrm{NO}_{3}^{-}$in the nutrient solution is possibly linked to the plant $\mathrm{NH}_{4}^{+}$toxicity. The $\mathrm{NH}_{4}^{+}$toxicity depends on plant species and affects the optimal plant growth by: (i) impairing uptake of nutrients; (ii) inhibition 
of secondary growth by acidification of the rooting medium; (iii) alterations in intracellular $\mathrm{pH}$ and osmotic balance; and (iv) altered phytohormone metabolism (Gerendás et al., 1997; Kronzucker et al., 1999; Britto \& Kronzucker, 2002). Unlike plant $\mathrm{N}$ nutrition based on $\mathrm{NH}_{4}^{+}$, even under a high content or exclusive in the growth medium, $\mathrm{NO}_{3}^{-}$ does not cause toxicity injuries to the plants. Yet, the results demonstrated that $P$. maximum grown in a nutrient solution where $\mathrm{NO}_{3}{ }^{-}$was the predominant $(85 \%)$ or sole $\mathrm{N}$ source did not perform better and/or had worse perform in terms of growth response and production than forage plants grown with the $\mathrm{NO}_{3}{ }^{-}$and $\mathrm{NH}_{4}^{+}$mixture at the ratio of $70-30$ or $55-45 \%$. Actually, besides the beneficial effects associated with plant hormones, an equilibrated $\mathrm{NO}_{3}{ }^{-}$and $\mathrm{NH}_{4}^{+}$mixture is able to enhance plant growth by other ways such as increasing plant $\mathrm{N}$ uptake (Kronzucker et al., 1999) and saving energy costs by using reduced $\mathrm{NH}_{4}^{+}$instead of $\mathrm{NO}_{3}^{-}$(Bloom et al., 1992). Based on the latter hypothesis, previous studies reported that adding $\mathrm{NH}_{4}^{+}$at a low level or up to the maximum level tolerable by a specific plant species in a growth medium containing $\mathrm{NO}_{3}^{-}$promotes positive yield and growth effects (Cox \& Reisenauer, 1973; Gerendás et al., 1997). It is reasonable to conclude that for $P$. maximum culture in a growth medium containing $15 \mathrm{mmol} / \mathrm{L}$ of $\mathrm{N}$ supplied by a $\mathrm{NO}_{3}^{-}$and $\mathrm{NH}_{4}^{+}$mixture, one may use up to $6.75 \mathrm{mmol} / \mathrm{L}$ as $\mathrm{NH}_{4}^{+}$, aiming to increase the plant growth responses without or having minimal $\mathrm{NH}_{4}^{+}$ toxicity risks.

Nitrogen concentration in P. maximum shoots and roots were distinctly affected by the $\mathrm{NO}_{3}^{-}: \mathrm{NH}_{4}^{+}$ratios in the growth medium (Figures $3 \mathrm{~A}$ and $3 \mathrm{~B}$ ). While the nutrient dilution phenomenon apparently governed the alteration in $\mathrm{N}$ concentration in the shoot tissue, root $\mathrm{N}$ concentration does not appear to follow this growth effect. In spite of the low dry matter production, roots of forage plants growing under a nutrient solution containing approximately $50 \%$ or more of the $\mathrm{N}$ as $\mathrm{NH}_{4}^{+}$showed no high $\mathrm{N}$ concentration in the root tissue. This can be attributed to a likely plantprotector mechanism (avoiding $\mathrm{NH}_{4}^{+}$uptake and/or through $\mathrm{NH}_{4}^{+}$efflux) against the $\mathrm{NH}_{4}^{+}$toxicity (Gerendás et al., 1997; Kronzucker et al., 1999; Britto \& Kronzucker, 2002) caused by $\mathrm{NH}_{4}^{+}$accumulation in plant tissue.

Surprisingly, free $\mathrm{N}-\mathrm{NO}_{3}{ }_{3}^{-}$and $\mathrm{N}-\mathrm{NH}_{4}^{+}$concentrations in the $P$. maximum shoot tissue were unaffected by the wide range of $\mathrm{NO}_{3}^{-}: \mathrm{NH}_{4}^{+}$ratios supplied in the nutrient solution (Figure 3A). In contrast, roots of grasses grown with a nutrient solution containing $85 \%$ or more $\mathrm{N}$ as $\mathrm{NO}_{3}^{-}$ exhibited higher concentration of both free $\mathrm{N}^{-\mathrm{NO}_{3}}{ }_{3}^{-}$and $\mathrm{N}-\mathrm{NH}_{4}{ }^{+}$compared with the other treatments (Figure 3B). These root and shoot data strongly suggest that the $P$. maximum root system must play an important role in $\mathrm{NO}_{3}^{-}$ reduction and root-to-shoot transport of free $\mathrm{N}_{-} \mathrm{NO}_{3}{ }^{-}$and $\mathrm{N}-\mathrm{NH}_{4}^{+}$. Marschner (1995) reported that $\mathrm{NO}_{3}^{-}$reduction directly in the root system instead of plant leaves depends on the $\mathrm{NO}_{3}{ }^{-}$content in the growth medium and plant species.

Similarly to plant productive and growth parameters, N use efficiency (NUE) also provides interesting information regarding $\mathrm{N}$ fertilization for forage production. The results revealed that a balanced proportion of $\mathrm{NO}_{3}{ }^{-}$and $\mathrm{NH}_{4}^{+}$in the growth medium maximizes the NUE by the $P$. maximum plants (Figure 3C). This finding is a good evidence that knowing performance and limitations of plant species $\left(\mathrm{NH}_{4}^{+}\right.$content tolerance) under $\mathrm{NO}_{3}^{-}$and $\mathrm{NH}_{4}^{+}$, it is possible to manage $\mathrm{N}$ fertilization for yield improvement by choosing $\mathrm{NO}_{3}{ }^{-}$or $\mathrm{NH}_{4}^{+}$-releasing fertilizers with or without combination of nitrification inhibitors. In fact, many researchers have investigated the nitrification inhibitors and their effectiveness under field conditions (Weiske et al., 2001; Singh et al., 2008), but few studies have focused on intrinsic plant species response to $\mathrm{NO}_{3}^{-}$and/or $\mathrm{NH}_{4}^{+}$supply.

\section{Conclusions}

The supply of a $\mathrm{N}$ form $\left(\mathrm{NO}_{3}^{-}\right.$and $\left.\mathrm{NH}_{4}^{+}\right)$mixture at an equilibrated proportion instead of $\mathrm{NO}_{3}^{-}$or $\mathrm{NH}_{4}^{+}$ predominantly or solely as $\mathrm{N}$ source in the growth medium enhances the forage yield of the tropical grass $P$. maximum by directly and positively affecting some shoot growth parameters (tillers and leaves) and by promoting better plant root system growth performance. The results obtained under controlled conditions provide basic knowledge of forage grass responses to $\mathrm{NO}_{3}^{-}$and $\mathrm{NH}_{4}^{+}$supply. However, further field research is important, to confirm in situ the advantages of supplying $\mathrm{NO}_{3}{ }^{-}$and $\mathrm{NH}_{4}{ }^{+}$together to tropical grass pastures.

\section{Acknowledgments}

The authors thank Coordenação de Aperfeiçoamento de Pessoal de Nível Superior (CAPES), Fundação de Amparo à Pesquisa do Estado de São Paulo (FAPESP) and Conselho Nacional de Desenvolvimento Científico e Tecnológico (CNPq) for providing the fellowships to the first, second and third authors, respectively.

\section{References}

BABIKER, I.S.; MOHAMED, M.A.A.; TERAO, H. et al. Assessment of groundwater contamination by nitrate leaching from intensive vegetable cultivation using geographical information system. Environment International, v.29, p.1009-1017, 2004. 
BLOOM, A.J.; SUKRAPANNA, S.S.; WARNER, R.L. Root respiration associated with ammonium and nitrate absorption by barley. Plant Physiology, v.99, p.1294-1301, 1992.

BRITTO, D.T.; KRONZUCKER, H.J. $\mathrm{NH}_{4}^{+}$toxicity in higher plants: a critical review. Journal of Plant Physiology, v.159, p.567-584, 2002.

COX, W.J.; REISENAUER, H.M. Growth and ion uptake by wheat supplied nitrogen as nitrate, or ammonium, or both. Plant and Soil, v.38, p.363-380, 1973 .

CRESTANA, S.; GUIMARÃES, M.F.; JORGE, A.C. et al. Avaliação da distribuição de raízes no solo auxiliada por processamento de imagens digitais. Revista Brasileira de Ciência do Solo, v.18, p.365-371, 1994.

DE BONA, F.D.; MONTEIRO, F.A. The development and production of leaves and tillers by Marandu palisadegrass fertilised with nitrogen and fertilization. Tropical Grasslands, v.44, p.192-201, 2010a.

DE BONA, F.D.; MONTEIRO, F.A. Marandu palisadegrass growth under nitrogen and sulphur for replacing signal grass in degraded tropical pasture. Scientia Agricola, v.67, p.570-578, 2010 b.

DREW, M.C. Comparison of the effects of a localized supply of phosphate, nitrate, ammonium and potassium on the growth of the seminal root system, and the shoot, in barley. New Phytologist, v.75, p.479-490, 1975.

GERENDÁS, J.; ZHU, Z.; BENDIXEN, R. et al. Physiological and biochemical processes related to ammonium toxicity in higher plants. Zeitschrift für Pflanzenernährung und Bodenkunde, v.160, p.239-251, 1997.

HAVLIN, J.L.; TISDALE, S.L.; BEATON, J.D. et al. Soil fertility and fertilizers: an introduction to nutrient management. New Jersey: Pearson Prentice Hall, 2005. 515p.

HELALI, S.M.; NEBLI, H.; KADDOUR, R. et al. Influence of nitrateammonium ratio on growth and nutrition of Arabidopsis thaliana. Plant and Soil, v.336, p.65-74, 2010.

HIROSE, T.; BAZZAZ, F.A. Trade-off between light- and nitrogenuse efficiency in canopy photosynthesis. Annals of Botany, v.82, p.195-202, 1998.

HOAGLAND, D.R.; ARNON, D.I. The water-culture method for growing plants without soil. Berkeley: Agricultural Experimental Station/University of California, 1950. 32p.

HUNT, L.A. Some implications of death and decay in pasture production. Journal of the British Grassland Society, v.20, p.27-31, 1965.

KRONZUCKER, H.J.; SIDDIQI, M.Y.; GLASS, A.D.M. et al. Nitrate-ammonium synergism in rice. A subcellular flux analysis. Plant Physiology, v.119, p.1041-1045, 1999.

LAURIAULT, L.M.; KIRKSEY, R.E.; DONART, G.B. Irrigation and nitrogen effects on tall wheatgrass yield in the southern high plains. Agronomy Journal, v.94, p.792-797, 2002.

LAVRES JÚNIOR, J.; MONTEIRO, F.A. Diagnose nutricional de nitrogênio no capim-aruana em condições controladas. Revista Brasileira de Ciência do Solo, v.30, p.829-837, 2006.

LIMA, J.E.; KOJIMA, S.; TAKAHASHI, H. et al. Ammonium triggers lateral root branching in Arabidopsis in an AMMONIUM TRANSPORTER1;3-dependent manner. The Plant Cell, v.22, p.3621-3633, 2010.
MARSCHNER, H. Mineral nutrition of higher plants. London: Academic Press, 1995. 889p.

McCRIMMON, J.N.; MILLS, H.A.; KARNOK, K.J. Effect of N-form on growth and nutrient content of creeping bentgrass. Journal of Plant Nutrition, v.15, p.1235-1252, 1992.

NELSON, D.W.; SOMMERS, L.E. Determination of total nitrogen in plant material. Agronomy Journal, v.65, p.109-112, 1973.

ONGARO, V.; LEYSER, O. Hormonal control of shoot branching. Journal of Environmental Botany, v.59, p.67-74, 2008.

RAHAYU, Y.S.; WALCH-LIU, P.; NEUMANN, G. et al. Rootderived cytokinins as long-distance signals for $\mathrm{NO}_{3}^{-}$induced stimulation of leaf growth. Journal of Experimental Botany, v.56, p.1143-1152, 2005.

REICH, P.B.; BUSCHENA, C.; TJOELKER, M.G. et al. Variation in growth rate and ecophysiology among 34 grasslands and savanna species under contrasting $\mathrm{N}$ supply: a test of functional group differences. New Phytologist, v.157, p.617-631, 2003.

SINGH, J.; SAGGAR, S.; GILTRAP, D.L. et al. Decomposition of dicyandiamide (DCD) in three contrasting soils and its effect on nitrous oxide emission, soil respiration activity, and microbial biomass - an incubation study. Australian Journal of Soil Research, v.46, p.517-525, 2008.

SMICIKLAS, K.D.; BELOW, F.E. Role of cytokinins in enhanced productivity of maize supplied with $\mathrm{NH}_{4}^{+}$and $\mathrm{NO}_{3}^{-}$. Plant and Soil, v.142, p.307-313, 1992.

TAKEI, K.; TAKAHASHI, T.; SUGIYAMA, T. et al. Multiple routes communicating nitrogen availability from roots to shoots: a signal transduction pathway mediated by cytokinin. Journal of Environmental Botany, v.53, p.971-977, 2002.

TEDESCO, M.J.; GIANELLO, C.; BISSANI, C.A. et al. Análise de solo, plantas e outros materiais. Porto Alegre: Departamento de Solos - UFRGS, 1995. 174p.

VICENTE-CHANDLER, J. Intensive grassland management in Puerto Rico. Revista da Sociedade Brasileira de Zootecnia, v.2, p.173-215, 1973.

WALCH-LIU, P.; IVANOV, I.I.; FILLEUR, S. et al. Nitrogen regulation of root branching. Annals of Botany, v.97, p.875-881, 2006.

WALCH-LIU, P.; NEUMANN, G.; BANGERTH, F. et al. Rapid effects of nitrogen form on leaf morphogenesis in tobacco. Journal of Experimental Botany, v.51, p.227-237, 2000.

WANG, X.; BELOW, F.E. Root growth, nitrogen uptake, and tillering of wheat induced by mixed-nitrogen source. Crop Science, v.32, p.997-1002, 1992.

WANG, X.; BELOW, F.E. Cytokinins in enhanced growth and tillering of wheat induced by mixed nitrogen source. Crop Science, v.36, p.121-126, 1996.

WEISKE, A.; BENCKISER, G.; OTTOW, J.C.G. Effect of the new nitrification inhibitor DMPP in comparison to DCD on nitrous oxide $\left(\mathrm{N}_{2} \mathrm{O}\right)$ emissions and methane $\left(\mathrm{CH}_{4}\right)$ oxidation during 3 years of repeated applications in field experiments. Nutrient Cycling in Agroecosystems, v.60, p.57-64, 2001.

ZHANG, H.; FORDE, B.G. Regulation of Arabidopsis root development by nitrate availability. Journal of Experimental Botany, v.51, p.51-59, 2000.

ZHANG, H.; JENNINGS, A.; BARLOW, P.W. et al. Dual pathways for regulating of root branching. Proceedings of the National Academy of Sciences of USA, v.96, p.6529-6534, 1999. 